\title{
THE MEASURE OF CONSUMPTION TAXES
}

\author{
B. U. RATCHFORD*
}

The measure of a tax is that quantitative feature or characteristic of the tax base to which the tax rate is applied to show the amount of the tax due. The base or object of the tax is the person, property, act, or privilege upon which the tax is levied. The characteristics most frequently used as measures are: (I) monetary value or price; (2) weight; (3) volume; and (4) the number of units. Two or more of these characteristics may be used together to produce a variation in rates. For example, one state levies a sales tax of one mill on all cigarettes which sell for not more than one cent each, but the rate is 20 per cent of retail price if they sell above that figure. Similarly, the federal excise tax on the manufacture of cigarettes is based on the number of cigarettes produced but varies with the weight.

The purpose of this article is to discuss the problems which most frequently arise in connection with the concept of the measure of consumption taxes. At times it is difficult to differentiate problems affecting measure from problems of exemption, enforcement, or general administration. But since the latter are dealt with in other articles in this symposium, the discussion here will, in so far as possible, be confined exclusively to problems peculiar to the tax measure. No attempt is made to present a complete catalog of all statutory provisions and regulations in all jurisdictions. Rather, the principal effort is to describe the tax measures most generally used and to discuss the problems which have proved to be most troublesome.

Many of the particular or selective excise taxes and all general sales or transaction taxes are measured by monetary value. This is the measure which gives rise to nearly all the problems. If measurement is by weight, volume, or number of units, there is little room for misunderstanding. ${ }^{1}$ There may be difficulty in discovering the taxable transaction or in collecting the tax, but those are problems of enforcement and not of the concept of measure. The gasoline tax provides an important exception. Problems concerned with the measure of this tax will be canvassed briefly; the remainder of the discussion will deal with consumption taxes which are measured by monetary value.

\footnotetext{
* B.S., I926, Davidson College; A.M., I927, Ph.D., 1932, Duke University. Associate Professor of Economics, Duke University. Author, American State Debts (1941). Contributor to economic and tax journals.

${ }^{1}$ One such misunderstanding did arise in Michigan, where state law levied a tax of five cents per pound on "containers of malt syrup and malt extract." The court held that "The method of computing the poundage tax ... is by weighing the entire contents of the containers and making no deduction for liquid ingredients." Secretary of State v. Potter, 252 Mich. 460, 465, 233 N. W. 380, 38r (1930).
} 
In theory the gasoline tax is a tax on the ultimate consumer. The logical point at which to levy and collect such a tax would therefore seem to be the sale for final consumption. But administrators soon found that the tax could be collected much more easily and efficiently from wholesalers, distributors, and processors. This was agreeable to the trade, since it saved much clerical work and freed retailers from worry. Consequently, all states now provide that the tax shall be collected in the early stages of distribution upon amounts received by distributors. ${ }^{2}$ But distributors suffer losses due to shrinkage, evaporation, and wastage; it is from this physical fact that there arises the major problem in connection with the measure of the gasoline tax.

The federal tax on gasoline includes no allowance for such losses, and there appears to be no constitutional doctrine to require it. The problem presented, is, therefore, merely a question of whether and, if so, to what extent a taxing jurisdiction will recognize and make concession for these unavoidable costs in gasoline distribution. All the states save two at the present time do make such an allowance; in $3^{6}$ jurisdictions it is done by statutory provision, in two it has been established by administrative ruling, in the others it is apparently allowed in practice without any formal provision. ${ }^{3}$ Two states, Minnesota and Virginia, provide that a part of the allowance must be passed on to retailers. West Virginia alone employs the refund method of administering the deduction policy. ${ }^{4}$ The allowance is most often stated as a percentage of the taxable gallonage, although in several states it is a percentage of the tax. While in a few instances the purpose of the deduction is not specified, it is elsewhere expressly declared to be the provision of compensation for evaporation, shrinkage, loss in handling, cost of collection, or combination of these factors. Notwithstanding the seeming clarity of purpose, Louisiana at least has experienced litigation over the meaning of the grant. The supreme court of that state declared a year ago that the legislative history of the measure clearly shows the deduction to be an allowance for "unavoidable losses in handling" and not a donation, though it conceded the tax could be levied on only 97 per cent of actual gallonage. ${ }^{5}$ The distributor's contention had been that the statutory allowance was over and above the actual physical losses incurred, being computed, therefore, on the amounts sold, and not the amounts received, by it. ${ }^{6}$

The same litigation found the state seeking means to prevent distributors from taking advantage of the fixed statutory allowance, in Louisiana three per cent, where actual losses are much less. In this effort, however, the state met its second rebuff

\footnotetext{
${ }^{2}$ For a case upholding a provision of this kind see Standard Oil Co. v. Fitzgerald, 85 F. (2d) 799 (C. C. A. 6th, 1936).

${ }^{3}$ Allowances for Cost of Collection, Shrinkage, and Evaporation-Gasoline Tax (Fed. Tax Adm'rs, I94I) REsEARCH BuLl. RB-68, at $\mathrm{I}$.

Id. at $2-4$.

State v. Sinclair Refining Co., I95 La. 288, I96 So. 349 (I940); see also the earlier case of Statc v. Standard Oil Co., r9o La. 338, I82 So. 53 1 (1938).

'Inasmuch as the Louisiana statutory allowance referred only to losses, apparently neither distributor nor court considered that it might be regarded as one for cost of collection, leaving physical losses to be compensated to the extent actually incurred. On allowances for cost of collection, see infra.
} 
at the hands of the Louisiana supreme court. . Just recently, in Minnesota, state constitutional provisions directed against taxation for a private purpose and irregular legislative appropriations were invoked to supplement the argument in terms of legislative intention; but with the same result. 8 This course of litigation suggests that, to the extent the statutorily-fixed percentages exceed actual experience, Illinois stands to gain by its provision allowing deduction only of actual costs, not exceeding two per cent, as do the ten states which handle the matter by administrative ruling or practice. States with a set rate of one per cent are of course not unduly disadvantaged, nor is Pennsylvania, which uses a rate that declines from two to one-half of one per cent as the amount of tax increases. But a flat two or three per cent rate is almost as common as the one per cent, while South Dakota allows four per cent. ${ }^{9}$ Clearly, a reduction in percentage can be achieved by statutory amendment, and the Ig4I sessions have seen numerous bills introduced to this end. Contrariwise, however, North Carolina has just abandoned a one per cent allowance for a $2-I^{1} / 2^{-I}$ per cent rate modeled on the Pennsylvania sliding-scale arrangement. ${ }^{10}$

\section{Elements of Price}

As indicated above, monetary value is used as the measure of most consumption taxes. Provisions making the formal levy usually specify "gross receipts," "proceeds from sales," "gross sales," or "gross income" arising from sales. These all represent totals arrived at by adding up individual sales, which, in turn, represent the products of prices times number of units. In the computation of the tax, then, the starting point must be the concept of price.

\section{Discounts}

One of the first problems to arise concerns the propriety of allowing cash, trade, or quantity discounts as deductions from the list price. The usual practice is to allow any discount which in reality establishes a new selling price. Many laws specifically make such provision, while in other cases it is made by regulations or practice. The Michigan regulations state: "Cash, trade, quantity and employees' discounts are obviously used in arriving at a sales price and are deductible."11 In Ohio, however, discounts are deductible only if taken at the time of sale. ${ }^{12}$ The North Carolina law contains a substantially similar provision; in relation to time or credit sales, "gross sales" are defined to mean "the sales price charged on the books for such sales, without allowance for cash discounts."13 This clause, however, is inconsistent with another section of the law which allows merchants to report and pay taxes on the basis of

\footnotetext{
${ }^{7}$ Cases cited supra note 5. In the Sinclair case actual losses were less than one per cent.

${ }^{8}$ Arneson v. W. H. Barber Co., 297 N. W. 335 (Minn. 194I) (3\% allowance "much greater than the actual evaporation and loss").

- Supra note 3, at 9; Crawford, The Gasoline Tax in the Uni ted States (1936) 15, I7.

${ }^{10}$ N. C. H. B. No. 388, I94I. ${ }^{11}$ Mich. Rules and Reg. (1938) 15.

${ }^{12}$ Ohio Rules and Discussions (1939) 27.

${ }^{23}$ N. C. Code (Michie, 1939) $\$ 7880$ (156) e (9).
} 
actual collections. ${ }^{14}$ For if a discount is allowed it is obvious that such amount will never be collected and hence the merchant will never become liable for the tax on it.

On the other hand, the Utah regulations state that "if the price upon which the tax was computed and paid is subsequently readjusted (by discounts, rebates, bonuses, etc.) a proper credit may be taken against the tax due on a subsequent return."15 The Internal Revenue Code contains a similar provision governing federal excise taxes. ${ }^{16}$ The Washington regulations contain what is probably the clearest and fairest statement on the point; "the gross proceeds actually derived from the contract and the selling price are determined by the transaction as finally completed."17

The supreme court of Michigan was called upon to decide whether, in the absence of specific statutory provision, amounts represented by cash discounts were taxable. ${ }^{18}$ The state contended that they were a part of gross receipts and, on the expense side, were a cost of doing business, which the act did not allow as a deduction. The court ruled that they were not a part of gross receipts and hence not taxable. The same rule was applied to trade and quantity discounts, the court holding: ${ }^{10}$ "... the quantity discount agreements ... do not contemplate refunds on the purchase price of merchandise, but determine the purchase price in advance of the actual sale. To hold otherwise would result in charging plaintiff more than three percent of the proceeds of the retail sales..." The position of the Michigan court and of the great majority of the states on discounts is sound and proper. Ohio and North Carolina have no sound justification for extending the terms "receipts" and "gross sales" so as to include amounts which retailers never receive.

\section{Transportation, Installation, and Service Charges}

Contract or quoted prices frequently include charges for transportation, installation, and service for a specified time. Where that is true, sales tax laws almost always apply to the full contract price. When stated separately such charges may or may not be taxable; in general they are exempt, but a few states look beyond form. For example, the Illinois regulations state that "whether or not transportation charges may be deducted by the seller from the selling price ... does not depend upon the separate billing thereof but depends upon whether the seller assumes responsibility for payment of transportation charges to a designated place ..."20 On the other hand, the Kansas regulations exempt all such charges, regardless of the arrangement. Under use taxes, the practice is substantially the same, although Kansas, North Carolina, Oklahoma, and Washington require that transportation charges from retailer to user be included for the tax computation.

Most laws levying excise taxes prohibit the deduction of transportation charges between manufacturers or wholesalers and retailers, regardless of the place where

\footnotetext{
${ }^{14} 1 d . \$ 7880(156)$ i.

${ }^{10}$ INT. REv. CODE $\$ 3443$ (a) (2).

${ }^{25}$ Utah Reg. (1939) 26.

${ }^{18}$ Standard Oil Co. v. State, 283 Mich. 85,276 N. W. 908 (1937).

${ }^{10} \mathrm{Id}$. at $9 \mathrm{r}, 276 \mathrm{~N}$. W. at $9 \mathrm{II}$.

${ }^{30}$ Ill. Rules and Reg. (May 28, 1940) Rev. Rule No. 25.
} 
the title may pass. ${ }^{21}$ California and Oklahoma, however, discriminate in favor of automobile purchasers on this point. They provide that the tax shall be based on factory or f.o.b. price plus all accessories and equipment. Most federal excise taxes are levied at the point of manufacture or production and all transportation, delivery, insurance, installation, and other like charges are excluded if they are satisfactorily separated. The selling price, however, includes "any charge for coverings and containers of whatever nature, and any charge incident to placing the article in condition packed ready for shipment."22 Years ago the Philippine court held that where it was customary to sell hemp baled, the cost of baling was a part of the price and was subject to an excise tax measured by the "actual selling price" of hemp. ${ }^{23}$

\section{Interest and Carrying Charges}

The sales tax laws or regulations of at least five states-California, Colorado, Kansas, Oklahoma, and Washington-provide that interest and carrying charges will not be considered as part of the taxable price if they are separately stated. The North Carolina regulations make the same provision only for furniture stores. By court ruling, the Philippine sales tax does not apply to interest received on installment payments when title to the goods sold passed at time of sale. ${ }^{24}$ What the practice may be in other jurisdictions is not indicated, although it is probable that it follows a similar pattern.

In some lines of business, such as furniture and jewelry, where time or instalment sales are the rule, it is customary to quote credit or time prices and allow discounts for cash. To avail themselves of the above provisions, merchants would have to make a definite allocation of selling prices to cost of article and carrying charges. In lines where both gross profit margins and carrying charges are large it would appear that merchants, in the absence of close and efficient supervision, could reduce their tax liability considerably by ascribing most of their gross profit margins to carrying charges. Perhaps it was to guard against this contingency that the regulations in Kansas, Oklahoma, and Washington require the charges to be billed separately to the customer. The Washington ruling adds that "amounts added to the base price .... on account of failure of the buyer to make any payment at the time specified in the agreement . . . are a part of the selling price and subject to the Retail Sales Tax."25

Taxes

Typical laws and regulations applicable to sales and use taxes provide that specific excise taxes levied by the Federal Government or the state shall not be included in taxable receipts. Manufacturers' excise taxes, however, are not usually deductible and

${ }^{21}$ Cf. Gee Coal Co. v. Department of Finance, 36I Ill. 293, I97 N. E. 87I (1936); State v. Menefee Motor Co., 18 La. App. 694, 139 So. 6r (1932).

22 INT. REv. CODE $\$ 3441$.

${ }^{23}$ Inchausti \& Co. v. Cromwell, 20 Philippine 345 (rgrr).

24 Bachrach Motor Co. v. Posados, 53 Philippine 999 (1929).

${ }^{25}$ Wash. Rules and Reg. (1939) 51. 
some states provide that no taxes shall be deducted unless they are paid directly by the person or firm making the return. California requires proof that the sales tax has not been absorbed.

The Michigan court has ruled that the federal tax on gasoline is a tax on the retail sale and that it and the state sales tax attach at the instant the sale is made; consequently, "the federal tax has not become a part of the sale price, but is a fund, which when collected is payable by the manufacturer to the federal government. Such fund does not become a part of the 'gross proceeds' realized by the manufacturer from the sale ..."26 The Illinois court, however, has held that the federal gasoline tax and other similar taxes are a part of the cost of the property sold by retailers and must be included as a part of the selling price. ${ }^{27}$ This apparent conflict is evidently due to the fact that in the Michigan case the firm which paid the federal tax was the same one which made the retail sale, while in the Illinois case there was first a sale to a retailer who then sold to the consumer. The Michigan regulations of $x 939$ rule that only those who pay the tax directly to the Federal Government may deduct it; others may not, since "they are not collecting such amount from the customer as a tax, but are merely reimbursing themselves for a tax which they have previously been required to pay." ${ }^{28}$ This position gives a slight advantage to the integrated oil company which sells directly to consumers.

The New York court has held that New York City may not, for its sales tax, require the inclusion in gross receipts of the amount of the state gasoline tax. The court stated that the gasoline tax was definitely on the purchaser and that the state enabling act did not, "either by express language or manifest intention, authorize the imposition upon the purchaser of double taxation, that is, a tax upon a tax."20 Most sales tax laws exempt the sale of gasoline and other commodities which bear heavy excise taxes.

With regard to their own sales taxes, North Carolina and Michigan, and perhaps other states, use what is known as the ro3 per cent formula. That formula assumes that merchants pass the tax on to consumers as required by law. Gross receipts are then considered as ro3 per cent of taxable receipts and the tax is paid on roo per cent. Illinois has perhaps gone as far as has any state in restricting deductions of the state sales tax itself. The regulations point out that the tax is on retailers and not on consumers; that retailers may shift the tax either by stating it separately or by including it in the quoted price, but "Regardless of how the retailer may set up his selling price he is required to pay a tax measured by his gross receipts." ${ }^{30}$ Thus, if a merchant adds three cents to a dollar article his taxable gross receipts will be a dollar and three cents.

In federal practice, the Bureau of Internal Revenue ruled, with respect to excise

${ }^{26}$ Standard Oil Co. v. State, supra note I8, at $95-96,276$ N. W. at 912.

${ }^{27}$ People v. Werner, 364 Ill. 594, 5 N. E. (2d) 238 (1936).

${ }^{28}$ Mich. Rules and Reg. (1938) I4.

${ }^{29}$ Socony-Vacuum Oil Co. v. City of New York, 247 App. Div. 163, 166, 287 N. Y. Supp. 288, 291, $a f f^{\prime} d, 272$ N. Y. 668,5 N. E. (2d) 385 (1936).

${ }^{30}$ Ill. Rules and Reg. (r939) art. 20. 
taxes levied by the Revenue Act of IgI8, that the tax might be deducted from the selling price if it were separately stated. In a case involving this point the Supreme Court refused to allow a refund where the tax had not been so segregated, and, by implication, cast doubt on the Bureau's power to make such a ruling. ${ }^{31}$ Probably as a result of this obiter dictum it is now provided that "there shall be excluded the amount of tax imposed ... whether or not stated as a separate charge."32

On theoretical as well as practical grounds a consumption tax should not be treated as an inherent element of price. The Mississippi supreme court has had occasion to apply this view in litigation by a vendor of sand and gravel to recover the amount of sales tax on the transaction. ${ }^{33}$ The buyer's contention that the tax was included in the stipulated purchase price was rejected on the ground that a tax is necessarily added to the price fixed by contract.

During the present year state legislatures have considered many bills to prevent a "tax on a tax." Much of this concern arises because of the announced intention of laying the tax only on the last transaction before the goods pass into the hands of the consumer. It is a commendable concern, for pyramiding should be avoided as far as possible, but it is largely futile, since only a small part of the total tax burden is represented by specific commodity taxes which can be identified and isolated.

\section{Prices below Fair Market Price}

When legislators levy a tax to be measured by price, they presumably have in mind a price to be arrived at by parties dealing at arm's length. When the tax is levied on producers or dealers in the early stages of distribution, it may be profitable for the taxpayer to organize a subsidiary to take the product at a nominal profit and then sell it to the trade at a much higher price. Such a practice is another example of the use of a fictitious personality to reduce taxes. To cover this kind of contingency the 1932 and later Revenue Acts have provided that when goods are sold at less than the fair market value the tax shall "be computed on the price for which such articles are sold, in the ordinary course of trade, by manufacturers or producers thereof, as determined by the Commissioner." 34

A circuit court of appeals upheld and applied this section in a case decided in 1936. A cosmetics firm had for several years been selling its products to the trade at a fixed and established price, which was far above cost of production. It then organized a selling company which bought the products from the parent company at a fair profit and sold them to the trade at the old, established prices. The court held that the transactions were not at arm's length and allowed the Commissioner to compute the tax on the old prices. ${ }^{35}$ Following this decision the Revenue Act of 1939

${ }^{31}$ Lash's Products Co. v. United States, 278 U. S. 175 (I928).

${ }^{33}$ INT. REv. CODE $\$ 344$ I (a).

${ }^{33}$ Woodrich v. St. Catherine Gravel Co., 195 So. 307 (Miss. 1940).

s4 See (April ro, 1941) i State TAx Rev. No. 12.

${ }^{36}$ Now INT. REv. Code $\$ 344$ I (b) (3).

${ }^{36}$ Bourjois, Inc. v. McGowan, 85 F. (2d) 5 ro (C. C. A. 2d, 1936). Another case, essentially similar although somewhat more involved, is Inecto, Inc. v. Higgins, 21 F. Supp. 4I8. (S. D. N. Y. 1937). In 
added a paragraph to the section levying the cosmetics tax, defining the conditions under which transactions would, prima facie, not be at arm's length. ${ }^{36}$ Incidentally, this is an example of the unfortunate tendency of the Bureau to have federal tax legislation amended to cover every particular case which arises. It was the less necessary in this instance since the original, general provision had been upheld. This practice results in long, detailed, rigid, and cumbersome laws directed at particular situations rather than general flexible provisions which can be adjusted to cover new situations as they arise.

Problems such as those described above are not likely to arise often under state laws since most of the state excise taxes are levied upon retail sales. Nevertheless, five states-Arizona, Mississippi, New Mexico, Washington, and West Virginia-have included in their sales tax laws provisions substantially similar to the federal provision. Apparently no litigation or serious interpretive problems involving them have arisen. But that states may possibly become concerned over sales below fair market value resulting from intense competition because of their effect on tax revenues, is suggested by the official designation given an anti-loss-leader bill introduced in the 194I session of the Ohio General Assembly. It reads: "To prohibit the sale of cigarettes as "lossleaders' with intent to injure or to destroy competition, and to stabilize and increase collections under the cigarette tax laws." ${ }^{37}$ However, the draftsman apparently added stabilization of tax collections merely as a possible selling point, since the Ohio cigarette tax is measured by the number of cigarettes sold and not by their price. Administrators advise, moreover, that this bill was not likely to receive serious consideration. $^{38}$

\section{The Computatton of Taxabie Receipts}

After determination of the selling price which is to be used in computing taxable receipts, the next step in computation of the tax is to determine the total of taxable gross receipts or gross proceeds of sales. At this stage several problems arise, some of which are now considered.

\section{Credit Sales}

As the accountant uses the term, gross receipts include credit as well as cash sales. In their sales tax laws, however, a majority of the states allow merchants who do a credit business to report on a cash basis and pay the tax as collections are received. In this way the merchant does not have to pay the tax on any part of his uncollectible accounts. In some states the privilege of reporting on a cash basis is extended to all in the law itself, while in others special permission must be obtained from administrators. In Illinois, use of the cash basis is mandatory; the law states

the latter case the district court discussed at some length the various elements to be considered in determining whether a transaction was at arm's length.

${ }^{38}$ INT. REv. CODE \$340r.

${ }^{37}$ Ohio Am. S. B. No. 158, 1941 .

${ }^{38}$ Kavanaugh, Federal Experience with Constımption Excises, infra this issuc, states that the federal gasoline tax is based on quantitative measurement for analogous reasons. The same article also deals more fully with price determination for tax purposes in the case of intercompany sales. 
that "In the case of charge and time sales the amount thereof shall be included only as and when payments are received by the seller,"39 and the regulations hold that "credit transactions ... do not become part of gross receipts until payments are actually received by the seller." 40 Some states restrict the privilege of deferred payment to charge accounts which extend over 60 days or more. In Kansas the privilege is not available if the credit is "covered by negotiable note or notes, or an assignable conditional-sales contract."

Several states require retailers to collect the use tax. Generally such states allow the same practice in regard to credit sales for use tax purposes as for sales tax purposes. In some states sales tax regulations are, by a general statement, extended to cover the administration of the use tax wherever applicable. Kansas and Utah, however, are exceptions. Kansas allows payment of the sales tax on a collection basis but requires payment of the use tax on a sales basis. ${ }^{41}$ In Utah the opposite conditions prevail. ${ }^{42}$

The states are moving to limit or restrict the privilege of deferring the payment of the tax on credit sales. Five-California, Michigan, Ohio, Oklahoma, and Utah-, of which three originally allowed deferred payment, now require that the sales tax be paid on credit sales the same as on cash sales. The severity of this restriction is increased by the fact that only Utah allows any refund, deduction, or credit for losses or bad debts." ${ }^{43}$ The Ohio regulations state:44 "If the account is under paid in whole or in part by the consumer, the tax is lost to the vendor and no claim for refund of the tax will be allowed." In a recent case a Michigan taxpayer contended that the term "gross proceeds" could not logically include: (I) balances due on conditional sales; (2) deferred payments due on credit sales; and (3) amounts represented by bad debts and credit losses. The court held that the provisions of the law were plain and that the legislature had the power to define the term so as to include the above elements. ${ }^{45}$ The Federal Government does not allow deferred payment on ordinary credit sales, but with leases, instalment sales and conditional sales, taxes become due on the payments as they are made. ${ }^{46}$

\section{Sales Returns and Allowances}

A large majority of sales tax laws and regulations specifically allow taxpayers to claim credit for returned goods. As none prohibits such deductions, it may be assumed that in those states where the law is silent the practice is allowed. Most states, however, limit the deduction strictly to returns wherein the full purchase price is refunded, either in cash or credit, and a few specify that the tax must be included in such refund. Some of the reasons for such a careful limitation and some problems which may arise are suggested by the California regulations. These first enumerate

\footnotetext{
${ }^{30}$ Ill. Stat. Ann. (Jones, I940) $\$ 1 \times 9.450$.

${ }^{\circ}$ Ill. Rules and Reg. (1939) II. 11 Kan. Reg. and Rulings (1940) $36,83$.

${ }^{\$ 3}$ Utah Laws 1939, c. 103, \$5; Utah Laws 1937 , c. II4, \$7.

${ }^{4}$ Utah allows credit to the vendor "for taxes paid on sales represented by that portion of an account determined to be worthless and actually charged off for income tax purposes . . ." Utah Laws 1939, c. 103, $\$ 5$.

${ }^{45}$ Gardner-White Co. v. Dunckel, 296 Mich. 225, 295 N. W. 624 (I94I).

"INT. REV. CODE $\$ 344$ I (c).
} 
certain reasons under which the returns must be justified, providing in such event for full refund to the customer, including tax. They then continue: ${ }^{47}$

Even if the full sale price is credited no deduction may be taken therefor . . . if the facts and circumstances indicate that the amount credited is an allowance for used property traded in on another purchase.

If there has been a substantial use of the property and the credit is pursuant to an agreement that the full selling price would be allowed on the purchase of property of substantially greater value, or if the customer purchases other property and is charged a price greater than another person would be charged for the same or similar property, it will be presumed that the contract of sale was not rescinded and the property was "traded in."

Washington regulations are strict in regard to the time element. They provide that "If the property is not returned within ten days from the date of sale, a presumption is raised that the property returned is not returned goods but is an exchange."48

The laws of some states, such as Utah and Washington, are sufficiently liberal to allow credit for adjustments and allowances of less than the full sale price. The Washington regulations provide for bona fide refunds, credits, and allowances given "on account of defects in goods sold," while the Utah provision is that"

Where any taxable article is returned to the vendor thereof for adjustment or replacement ... and a new article given pursuant to guarantee, free or at reduced price, the tax shall be computed on the actual amount, if any, to be paid by the vendor [sic] for the new article.

Kansas has a substantially similar regulation, although its law contains the narrow or restricted clause above mentioned. This may be explained by the fact that Kansas is one of the few states which allow the value of property traded in at the time of sale to be deducted from the sale price. Under this condition it would make no difference whether the property accepted was treated as a return sale or as a trade-in. The Internal Revenue Code allows a credit against, or a refund of, excise taxes "when the price on which the tax was based is readjusted by reason of a return or repossession of the article ... or by a bona fide discount, rebate, or allowance . . ."0 The Federal Government and most of the states which have ruled on the point permit the deduction of refunds or credits made on returnable containers in the same manner as for returned goods.

\section{Bad Debts}

Several states have included provisions for the relief of retailers who pay taxes, voluntarily or involuntarily, on the basis of total sales and then are unable to collect some of their debts. Utah allows deductions written off for income tax purposes, while Kansas merely requires that the seller shall have written off the losses on his own books. Colorado requires that the merchant shall have written off the losses and that he be able to prove the accounts uncollectible. South Dakota, which allows payment on a collection basis only for conditional sales and lease contracts of sale, does

\footnotetext{
"Cal. Ruling No. 50, June 27, 1939.

"O Utah Reg. (1939) 27.

48 Wash. Rules and Reg. (1939) 50.

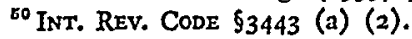


not allow the deduction of losses if the retailer finances the sales himself and repossesses the goods sold. If the sales are financed through a finance company, the tax is due at the time of sale and, in the event of repossession, the vendor may deduct any losses he suffers after sale of the repossessed goods. ${ }^{51}$

A tenable position regarding losses on account of bad debts must take account of the state's position on credit sales. If payment of the tax on a collection basis is allowed and if a large majority of the merchants affected follow that procedure, an allowance for credit losses is of little consequence. But where immediate payment of the tax is required on all sales, the refusal to allow losses is a distinct burden on the retailer. It is true that such allowances present another problem of administration and may constitute another avenue of evasion; but inasmuch as most of the states now have income taxes the policy of allowing losses under the two taxes might be coordinated, as has been done in several states. As an aid in this direction, South Dakota requires that all claims on account of losses for the previous year be filed in the January return. ${ }^{52}$ This should greatly simplify the administrative problem.

\section{Spectal Problems of Price and Gross Receipts}

In addition to the items discussed above there are certain problems affecting price, gross receipts, or both which quite often arise and which deserve some special comment. Such problems are treated briefly below.

\section{Goods Traded in or Repossessed}

In certain fields, used or second-hand goods are quite regularly accepted in part payment of new goods. The treatment of sales involving these trade-ins, as they are called, has provided a difficult problem in all states which levy sales taxes. There are three ways in which the matter may be handled. First, the value placed on the used goods may be allowed as a deduction from the sale price of the new article. Second, the sale of the new article may be taxed on its full sale price but the resale of the used goods may be exempted from the tax. Third, both sales may be fully taxable..$^{53}$ Only a few jurisdictions, including Kansas, New York City and North Dakota, use the first method, Kansas having just shifted from the second. ${ }^{54}$ Practice is about evenly divided between the second and third methods, with most of the Western states favoring the latter. While Iowa exempts the resale only to the extent of the trade-in allowance, most states using the second method exclude the sale regardless of the price. It is common with them, however, to make such exclusion only when the used goods were taken in exchange for new goods. For each new car that an automobile dealer sells he may have to sell two or three used cars, taking other used cars as part payment for them. ${ }^{55}$ The North Carolina court has ruled that the resale

\footnotetext{
E2 S. D. Rules and Reg. (1939) $28 . \quad 52$ Id. at 17.
}

${ }^{63}$ Apparently in the absence of any special provision both sales are fully taxable. State v. HallenbergWagner Motor Co., 34I Mo. 77I, ro8 S. W. (2d) 398 (1937); City of Philadelphia v. Heinel Motors, I6 A. (2d) 76I (Pa. Super. Ct. I940); Bedford v. Hartman Bros., I04 Colo. I90, 89 P. (2d) 584 (1939).

¿ Kan. S. B. No. 270, 194I, amending KAN. Rev. Stat. (Corrick, Supp. I939) 79-3602(h).

Ev The South Dakota supreme court has taken judicial notice of the fact that it is frequently necessary 
exemption does not apply to the sale of used cars accepted in the sale of other used cars. ${ }^{56}$

There seems to be a general tendency for states to switch to the third method, probably as the result of unsatisfactory experience with other methods. This tightening up of provisions is, no doubt, the more attractive to administrators because it increases yields at the same time that it reduces administrative problems. Litigation indicates that in the doctrines of neither statutory nor constitutional interpretation can the taxpayer find relief from such legislative action. Only a few months ago the "double taxation" contention was unequivocably disposed of by a Pennsylvania court in these words: ${ }^{57}$

Appellant contends that the effect of the decision of the court below is to impose double taxation. We find no merit in this contention. The tax is imposed on the purchaser, computed on the amount he has agreed to pay. The dealer is not required to pay any tax, since the ordinance only imposes on him the duty to collect from the purchaser, nor is the dealer required to pay any tax on the purchase of the new automobile acquired by it in the transaction since it has purchased the same for resale. When the defendant corporation proceeds to sell the car accepted by it in trade to a new purchaser, the latter enters into a totally distinct and separate transaction and is chargeable under the ordinance with the tax on the purchase made by him. In each instance, the tax has been levied upon the particular transaction with the respective purchaser.

Earlier, the Colorado supreme court had added that "there is no limit to the number of times a particular article of merchandise may be subject to a sales tax so long as it remains in the stream of commerce and goes through the regular channels of trade ..." 58 Similarly, the South Dakota supreme court has held that a sales tax law making both the sale of new goods and the resale of used goods fully taxable is not discriminatory against automobile dealers merely because their cash receipts are lower, in proportion to the total value of their sales, than is true with other stores..$^{50}$ Taxpayer challenge on the legislative front is, however, not necessarily so hopeless; the double tax argument has an appeal that provokes a sufficient number of bills to make the adoption of some, at least, a likelihood on the law of averages. ${ }^{00}$

If, as is usually professed, the primary purpose of sales taxes is to levy a tax once and only once on the final, retail sale of goods, then the first method is the one best fitted to attain that end. Under it the purchaser of each article, whether new or used, pays the tax on it. When purchasing a new article the original owner of the used

for automobile dealers to sell 15 used cars in order to dispose of five new ones. State v. Welsh, 65 S. D. 68,270 N. W. 852 (1936).

${ }^{68}$ McCanless Motors Co. v. Maxwell, 210 N. C. 725,188 S. E. 389 (1936).

${ }^{67}$ City of Philadelphia v. Heinel Motors, supra note 53 , at 764 . Sce also State v. Hallenberg-Wagner Motor Co., supra note 53 .

${ }^{58}$ Bedford v. Hartman Bros., supra note 53, at 194,89 P. (2d) at 585-586.

${ }^{60}$ State v. Welsh, supra note 55. See also General Tire Co. v. Oklahoma Tax Comm., 112 P. (2d) 407 (Okla. I94I).

${ }^{00}$ Thus of numerous bills introduced in the 194I legislative sessions several have been enacted. Scc, e.g., Colo. H. B. No. 355, I94x, excluding from gross sales the fair market value of exchanged property to be sold afterwards in the usual course of the retailers' business; N. M. S. B. No. 24I, 194I, which amends the state use tax to permit deduction of allowances for trade-ins from the purchase price. 
article, in effect, gets, on the tax originally paid, a rebate proportional to the services still remaining in the old article. Under the second method the purchaser of the new article, in effect, pays the sales tax on the sale of the second-hand article. From a broader viewpoint this may be desirable in that it introduces an element of progression into the sales tax, assuming that those who buy new articles are from a higher income level than are those who buy used goods. The North Carolina ruling cited above, however, vitiates this by making the tax apply to the sale of third-hand goods. The third method requires the payment of the tax twice on the same article, which is contrary to the general theory of the sales tax as it has been used in this country.

When goods are repossessed under conditional sales or similar contracts, problems similar to those involving trade-ins may arise. The methods of dealing with these problems are also similar. First, the merchant may be allowed a credit or a refund equal to the tax on the unpaid balance and be required to pay a tax when the repossessed goods are resold. Second, no credit or refund may be allowed but the resale may be exempted from the tax. Third, neither credit nor exemption may be allowed. This last method requires the payment of the tax a second time on a part of the value of the article, while under the second the merchant may lose if he sells the repossessed article for less than the unpaid balance. All things considered, the first method seems to be the fairest, as it is the one most commonly used. It is equivalent to treating the repossession as a sales return, and some states have grouped the two types of transactions together.

On the contrary, however, the supreme court of Michigan has ruled that vendors may not deduct unpaid balances on repossessed goods under a statutory provision allowing the deduction of "Credits or refunds for returned goods." ruling, the Michigan regulations were amended to provide that "Credits or refunds for returned goods . . . cover only such goods that are voluntarily returned for full exchange and do not include repossessions or recapture of merchandise by legal process . ..."62

Most states allow the credit or exemption only to the original vendor; if a finance company handles the transaction it is fully taxable. An Illinois rule, however, is an exception to the position generally taken; it states that, "the finance company acts as agent for the owner of the repossessed property, and is not liable for the payment of any ... tax with respect to the proceeds from the sales." 63

\section{Constructive Sales}

In certain circumstances taxes which are levied upon sales are extended to cover transactions which are not sales but which are designated as such for tax purposes. The concept of "sale" is treated in other articles" but certain aspects of the problem are pertinent to the problem of measure. For example, under the taxes levied on

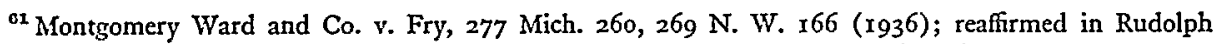
Wurlitzer Co. v. State Board of Tax Admin., 28I Mich. 558, 275 N. W. 248 (1937).

${ }^{02}$ Mich. Rules and Reg. (1938) I4. ${ }^{03}$ Ill. Rules and Reg. (1939) Rule No. 55.

' Consult Herman, Who Are Taxable?-Basic Problems in Definition tunder the Illinois Retailers' Occupation Tax Act; Cohen, The Taxable Transaction in Consumers Taxes, both supra this issue.
} 
admissions by the Federal Government and by certain states, complimentary tickets and passes are treated as having a value equal to the price charged "to other persons for the same or similar accommodations." ${ }^{\text {" } 5}$ In the same way, federal excise taxes apply to goods produced and used by the producers if they do not become ingredients of taxable products. They are taxable at the usual sale price of such goods. ${ }^{\circ 0}$ The sales tax laws of at least six states apply to goods consumed, withdrawn for use, or given away as gifts, prizes, or premiums by retail merchants. ${ }^{67}$ In most instances they are to be valued at the cost to the retailer.

In some states the withdrawal or use of goods has presented difficult legal problems and opened up avenues of avoidance. For example, the Michigan supreme court required the state to refund taxes paid on goods used in the operation of retail stores. $^{68}$ In North Carolina the attorney-general similarly ruled that since the tax was upon sales, such transactions, because they involved no sale, could not legally be taxed. Operators of large farms or other enterprises in the same state quite often conducted small stores in connection with such activities, thus making it possible for them to procure all of their supplies without the payment of the sales tax. In certain parts of North Carolina this constituted a serious problem of avoidance. Such enterprises are now required to pay the use tax on goods used or consumed.

Evidently the same problem has arisen in Illinois, but it has been met in a different way. Retailers are "permitted" to treat their entire purchases as made for resale, but if they do so they are liable for payment of the tax on goods used or consumed. In that case, wholesalers are not required to pay the tax on goods sold to the retailer. But "if a retailer elects not to pay the tax, he will be required to produce for the Department the name of his supplier and a statement of the value of the property used by him." 69

\section{Combination Sales of Goods and Services}

Most sales taxes in this country are levied upon the retail sale of tangible personal property. Often, however, such property is sold in conjunction with certain services and a lump sum is charged for the whole. The problem of dividing the total price into the part charged for services and the part charged for goods is a most difficult one. Most states have attacked the problem by classifying the various callings, occupations, and professions and indicating the tax liability of each. The classifications may be grouped under three broad headings. First come businesses which are primarily engaged in rendering services, but which may incidentally sell some tangible goods. Examples of such would be barbers, dentists, laundries, and physicians. These are usually exempted from the sales tax on their principal activity, but if they should sell tangible goods as a side line they are liable for the tax. Second are those businesses which are primarily engaged in selling tangible goods, but which may render some

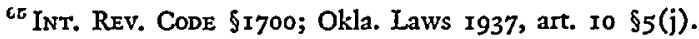

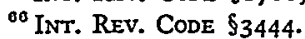

${ }^{67}$ California, Colorado, Illinois, Kansas, Oklahoma, and South Dakota.

${ }^{68}$ Montgomery Ward and Co. v. Fry, supra note 61, at 269, 269 N. W. at 170.

${ }^{60}$ IIl. Rules and Reg. (1939) Rule No. 75.
} 
services incidentally. Examples of this group are coal and ice dealers, florists, opticians, and photographers. These are usually subject to the tax on their total receipts, even though a part of their charges may be for services. Third are those businesses which fall between the two groups described above, and in which both services and the sale of goods play important parts. In this group fall automobile and shoe repair shops, morticians, and plumbers.

The general rule applied to this third group, which supplies most of the problems, is that if they keep separate records and make separate charges for goods and services, they are liable for the tax only on the goods sold. But often a single charge is made for both goods and services and it is almost impossible to make any accurate apportionment between the two. For example, the funeral director who makes a flat charge for a funeral would find it difficult to apportion his charge between car hire, supplies, and fee. Further, many of the units involved are small and have only the most elementary accounting systems, if any at all. To meet this situation many states have provided that such units may, in the absence of cost accounting systems, arbitrarily apportion a stated per cent of their receipts to services and the remainder to goods sold. The part of the charge representing taxable sales of goods varies from state to state. Shoe and harness repairmen are taxed on from 25 to $5^{\circ}$ per cent of charges and morticians on from 50 to 75 per cent, with 50 per cent the more common figure. Some states are finding it easier to require such units to pay a use tax on the goods they purchase and to exempt them entirely from the sales tax.

\section{Computation and Payment of the Tax}

The final step in the determination of consumption taxes involves, after the above problems have been solved, the computation of the taxes due and the payment of them to the state. This computation may be affected by the exact nature of the tax. Judged according to the base of the levy, there are two principal types of consumption taxes in use among the American states; one is nominally a privilege or occupation tax on retail merchants, measured by retail sales, while the other is a tax directly on each retail sale. Under the first type the retailer, after finally determining his taxable "receipts," "proceeds," or "gross sales," applies the tax rate-usually two or three per cent-and thus finds the amount of the tax he must pay. That ends the computation unless the state allows him a discount for his work in collecting the tax. But under the second type there may be additional complications, arising from the fact that application of the tax rate to individual sales seldom results in a tax measured in even cents. Consequently, the sum of the taxes computed on individual sales will be different from the tax computed on total sales.

\section{Computation of Tax on Single Sales or on Entire Account}

In the case of charge or credit accounts, the first problem is whether to compute the tax on each individual entry or on the entire account. Ohio regulations require that the tax be computed separately on each charge of a credit account. A charge is 
defined as the total sales price of goods ordered at one time. ${ }^{70}$ On the other hand, in Kansas, "the retailer will not add the tax to each individual charge sale at retail, but will compute and separately bill the tax on the total charge account." ${ }^{\text {"71 }}$ South Dakota has a similar provision. In Colorado the retailer "may assess the tax on each completed sale, or on the total sales for the day, week or month to each individual, provided that the full two per cent is collected and remitted on the account for each monthly period, plus any excess tax collected." 72

\section{Tax Collections v. Tax Payments}

The last phrase of the above quotation suggests another problem connected with those laws which impose the tax directly on retail sales. In applying the tax to small sales most states use either tax tokens or a system of brackets or "breaking points." Those brackets will usually, if consistently applied, yield an amount greater than that given by applying the tax rate to total taxable sales. In two cases the use of tokens and the bracket system has been contested on the ground that consumers are thereby forced to pay the tax at a rate higher than that levied by law. In the token case the court held that the arrangement was "for convenience in computing the tax" and arose "out of the necessity of the case." It held further that the retailer, who was the contestant, was not injured "since the tax is paid by the purchaser." case the court held that the extra cent required by the bracket system was "itself part of the purchase price" and that "it cannot become of immediate legal concern to the consumer that the ... retailer pays to the state but four and one-half mills ..."74 At least six jurisdictions specifically require that the retailer pay over to the state all taxes collected, even when they exceed the computed amount on his total sales. Thus the Colorado act states: "If any vendor shall, during any reporting period, collect as a tax an amount in excess of $2 \%$ of this total taxable sales, he shall remit to the state treasurer the full net amount of the tax herein imposed and also such excess ..."75 A similar provision has received judicial approval in Utah. ${ }^{70}$

In West Virginia especially, the operation of this type provision results in an effective tax considerably higher than the one nominally levied. The tax is imposed at the rate of two per cent, but retailers are required to collect the tax according to the following schedule: on sales below six cents, no tax; from six cents to $\$ 0.50$, one cent tax; from $\$ 0.5 \mathrm{I}$ to $\$ \mathrm{~T} .00$, two cents tax; thereafter, one cent of tax on each fifty cents or fraction thereof. The act then provides:" "No profit shall accrue to any person as a result of the collection of the tax levied by this article ... and the total of all taxes collected by such person shall be returned and remitted to the tax commis-

T0 Ohio Rules and Discussions (1939) 16.

${ }^{71} \mathrm{Kan}$. Reg. and Rulings (1940) $29 . \quad{ }^{72}$ Colo. Rules and Reg. (r939) 45.

${ }^{73}$ Morrow v. Henneford, 182 Wash. 625, 632, 47 P. (2d) 1016, 1019 (1935).

${ }^{74}$ De Aryan v. Akers, I2 Cal. (2d) 78r, 785, 87 P. (2d) 695, 697 (1939).

${ }^{75}$ Colo. Stat. AN. (x935) c. I44, \$r3.

${ }^{76}$ W. F. Jensen Candy Co. v. State Tax Comm., go Utah 359, 6I P. (2d) 629 (1936).

77 W. VA. CODE (1937) $\$ 999(5)$. 
sioner ..." These provisions probably give an effective tax which is nearer three than two per cent.

In the absence of specific statutory provisions, the Pennsylvania courts have held that, under the Philadelphia sales tax, "the receipt of the tax money by the vendor operates to create a constructive trust" and that the vendor is not entitled to retain any part of the tax. ${ }^{78}$ In New York City' a retailer had, by order of the Comptroller, collected sales taxes on certain sales which were legally exempt. The collections had been deposited with the city. Although a lower court ordered these returned to the retailer, ${ }^{70}$ the New York court of appeals reversed the decision, pointing out that the consumers had paid the tax and possessed a direct remedy against the Comptroller but that the petitioner was "not entitled to have returned to it this fund in which concededly it has no beneficial interest." 80

\section{Discounts to Dealers}

Common to both principal types of American consumption taxes is the practice of compensating producers, wholesalers, and retailers, especially the latter, who act as initial tax gatherers. The work of collecting, recording, and paying the tax monies over to tax officials imposes a considerable burden upon such parties. Shoup found that every store investigated in New York City reported a distinct increase in accounting costs because of the tax and that many estimated the extra cost at from five to ten per cent of the tax collected. ${ }^{81}$ In an effort to reduce retailer opposition to such taxes by compensating them for their quasi-public function, several states allow deductions from the computed tax. Missouri and Oklahoma allow discounts of three per cent if the tax is paid promptly. Ohio allows a three per cent discount on prepaid tax receipts. Colorado and Louisiana allow discounts of five per cent.

The most general use of discounts is found in the administration of state cigarette taxes. Of the 24 states which levy such taxes, 20 allow discounts ranging from three to ten per cent of the taxes collected to cover costs of affixing stamps. ${ }^{82}$ These taxes are collected by the use of stamps, which has usually proven the cheapest method of tax collection. Of all the major federal taxes, the cigarette tax has been by far the most cheaply administered. The Federal Government allows no rebate or discounts but does provide machines for attaching and canceling stamps. ${ }^{83}$ As a general rule the costs of collecting taxes should not exceed from two to four per cent; ${ }^{84}$ certainly anything above five per cent is excessive. Yet with cigarette taxes, which are inherently easy to administer, the states are paying out to private dealers an average of about seven and one-half per cent of collections; ordinary administrative costs must

${ }^{78}$ City of Philadelphia v. Heinel Motors, stipra note 53 , at 765 .

${ }^{70}$ Kesbec v. Taylor, 253 App. Div. 353,2 N. Y. S. (2d) 241 (1938).

${ }^{80}$ Kesbec v. McGoldrick, 278 N. Y. 293,297, r6 N. E. (2d) 288, 290 (1938).

sx Shoup, The Experience of Retailers under New York City's Sales Tax (r936) 30 BulI. Nar. Tax Ass'N I Io.

${ }^{82}$ TAX SysteMs OF THE WORLD (8th ed. 1940) 230-23I.

${ }^{83}$ INT. REV. CODE $\$ 2$ II2(a)(2).

84 For example, for the fiscal year 1939 the Michigan State Board of Tax Administration had total expenses equal to r.98 per cent of net collections. Mich. State Bd. Tax Admin., Ann. Rep. (I939) 4. 
be added to that. Very few discounts are allowed for the collection of other taxes, many of which are more expensive to collect than the cigarette taxes.

Further, there appears to be no relation between the amount of the tax per package and the discount allowed. It costs no more to affix a four cent stamp than to affix a two cent stamp yet the only two states which levy a four cent tax allow the maximum discount of ten per cent. The distribution of the discounts is as follows:

Taxper

package of

20 cigarettes

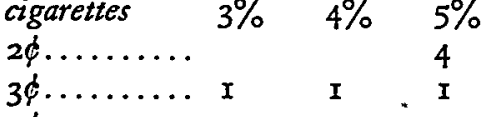

Discounts Allowed

$4 \phi$

It appears that the tobacco distributors were alert when cigarette taxes were being enacted and succeeded in having liberal provisions inserted for their benefit. Once established, such provisions tend to persist. There have been some reductions in recent years, but the allowances are still far too high. ${ }^{85}$

${ }^{85}$ Discounts to dealers are treated from the point of view of tax enforcement by Huston and Berryman, Collection and Enforcement of State Consumption Excise Taxes, stpra this issue. 